\title{
Bioguided screening for cytotoxic active constituents of Cuminum cyminum volatile oil
}

\author{
Mahmoud M. Abdel-Aal, Azza M. El-Shafae, Maged M. Abou-Hashem, Abd El-monem \\ M. Ateya and Mona Fekry \\ Department of Pharmacognosy, Faculty of Pharmacy, Zagazig University, 44519 Zagazig, Egypt \\ *corresponding author e-mail: mmabdelaal57@yahoo.com
}

\begin{abstract}
Volatile oils hold tremendous potential for the production of high quality plant based medicines. The aim of this study was to evaluate the cytotoxic activity of cumin volatile oil (CVO) against hepatocellular carcinoma (Hep-G ${ }_{2}$. In MTT (3-(4,5-dimethylthiazol-2-yl)-2,5diphenyltetrazolium bromide) assay, CVO showed potent cytotoxic activity against Hep- $\mathrm{G}_{2}$ cell line with $\mathrm{IC}_{50}=2.4 \mu \mathrm{g} / \mathrm{ml}$. Bioguided fractionation of $\mathrm{CVO}$ using silica gel column chromatography afforded two active fractions(VO-1and VO-2) with $\mathrm{IC}_{50}=0.6$ and $0.9 \mu \mathrm{g} / \mathrm{ml}$, respectively. GC-MS analysis was carried out for CVO and its two active fractions. Crystallization of active fraction VO- 1 lead to the isolation of cuminic acid with $\mathrm{IC}_{50}=6$ $\mu \mathrm{g} / \mathrm{ml}$. The structure of cuminic acid was established using IR, MS, ${ }^{1} \mathrm{H}-\mathrm{NMR}$ and ${ }^{13} \mathrm{C}-\mathrm{NMR}$.
\end{abstract}

Keywords: Cumin volatile oil, GC-MS, hepatocellular carcinoma (Hep-G $\left.\mathrm{G}_{2}\right)$.

\section{INTRODUCTION}

Active components of many volatile oils impressively exhibit amazing potential medicinal benefits. For instance, $\alpha$-pinene showed cytotoxic activity against Hep- $\mathrm{G}_{2}$, lung carcinoma,human ovarian adenocarcinoma, mammary adenocarcinoma, human cervical carcinoma and gastric carcinoma (Marianna et al., 2014); $\beta$-pinene showed cytotoxic activity against Hep- $\mathrm{G}_{2}$, lung carcinoma, human colorectal adenocarcinoma, breast carcinoma and human melanoma (Marianna et al., 2014); $\quad \gamma$-Terpinene showed cytotoxic activity against Hep-G $\mathrm{G}_{2}$, mouse leukemia , erythromyeloblastoid leukemia and melanoma (Marianna et al., 2014); myrcene showed cytotoxic activity against Hep- $\mathrm{G}_{2}$, human cervical carcinoma, human lung carcinoma, human colon adenocarcinoma, crown gall tumors, breast carcinoma, mouse leukemia and melanoma (Marianna et al., 2014); p-cymene showed cytotoxic activity against lung carcinoma and colorectal adenocarcinoma (Marianna et al., 2014) and cumin aldehyde possessed cytotoxic activity against human colorectal adenocarcinoma (Kuen-daw et al., 2016). It was reported that, cumin seed decreased the incidence of stomach and liver tumors and prevented the growth of breast and colon cancer cells (Daljeet et al., 2012). CVO showed dosedependent antioxidant activity which is responsible for its cytotoxic activity (Allahghadri et al., 2010).

Cumin (Cuminum cyminum), is a small annual herbaceous plant that belongs to family Umbelliferae. It is indigenous to Eastern Mediterranean countries and South Asia (Uma et al., 2017). It is noteworthy that there are considerable qualitative and quantitative differences of the $\mathrm{CVO}$ as reported by previous studies (Nicola et al., 2005; Latif et al., 2007; EL-Kamali et al., 2009; El-Ghorab et al., 2010; Nisha et al., 2014; Rasha et al., 2014). The variation in the chemical composition of CVO according to geographical source can be summarized in table (1). 
Table 1: Effect of geographical source on chemical composition of CVO

\begin{tabular}{|c|c|}
\hline Geographical origin & Chemical composition \\
\hline Italy & $\begin{array}{l}p \text {-Mentha-1,4-dien-7-al, cumin aldehyde, } \gamma \text {-terpinene, and } \alpha \text {-pinene } \\
\text { (Nicola et al., 2005). }\end{array}$ \\
\hline Iran & $\begin{array}{l}\alpha \text {-Pinene (29.1), 1,8-cineole (17.9) ,linalool (10.4) and limonene } \\
(21.5 \%) \text { (Latif et al., 2007). }\end{array}$ \\
\hline Central Sudan & $\begin{array}{l}\text { Cuminaldehyde (32.70), 2-caren-10-al (20.30), fenylglycol (15.76 ) } \\
\text { and } \gamma \text {-terpinene (11.72\% ) (EL-Kamali et al., 2009). }\end{array}$ \\
\hline Pakistan & Cuminal, $\gamma$-terpinene and pinocarveol (El-Ghorab et al., 2010). \\
\hline India & $\begin{array}{l}\text { Trans-dihydrocarvone (31.11), } \gamma \text {-terpinene (23.22), p-cymene (15.8), } \\
\alpha \text { - phellandrene (12.01), p-menth-2-en-7-ol (3.48) and } \\
\text { cuminlaldehyde constituted only } 0.58 \% \text { of the volatile oil (Nisha et } \\
\text { al., 2014). }\end{array}$ \\
\hline Egypt & $\begin{array}{l}\gamma \text { - Terpinene (22.7), } \beta \text {-pinene (19.2), cuminaldehyde (18.0) and } p \text { - } \\
\text { cymene (11.5\% ) (Rasha et al., 2014). }\end{array}$ \\
\hline $\begin{array}{l}\text { Current study } \\
\text { ( Egypt) }\end{array}$ & Cuminaldehyde (34.72) and cuminic acid (16.72\% ). \\
\hline
\end{tabular}

\section{MATERIALS and METHODS}

\subsection{Plant material}

The fruits were purchased from the registered famous Harraz stores in Cairo and kindly identified by Dr. Abd-Elhalim Abdel-Mogly, Prof. of Taxonomy, Flora Department, Agricultural Research Institute, Ministry of Agriculture, Cairo, Egypt. Voucher specimens were kept in the Pharmacognosy Department, Faculty of Pharmacy, Zagazig University, Zagazig, Egypt.

\subsection{GC-MS analysis}

GC-MS were carried on Shimadzu GC/MS-QP505-A, software:class 5000, searched library: Wiley Mass Spectral Data Base, column: DB 5.25m; 0.53mm ID:1.5um Film (J\&W SCIENTIFIC), carrier gas: He, ionization mode: EI, ionization voltage: $70 \mathrm{eV}$, temperature program: initial temperature was $40^{\circ} \mathrm{C}(30 \mathrm{sec})$, then was increased to $150{ }^{\circ} \mathrm{C}(1 \mathrm{~min})$ at rate 7.5 ${ }^{\circ} \mathrm{C} / \mathrm{min}$, until reached $250{ }^{\circ} \mathrm{C}$

(5min) at rate $7{ }^{\circ} \mathrm{C} / \mathrm{min}$, detector temperature : $280{ }^{\circ} \mathrm{C}$, injector temperature :
$280{ }^{\circ} \mathrm{C}$. Identification of the components of the CVO was performed by comparing their determined retention index (RI) with the reference of a homologous series of nalkanes $\left(\mathrm{C}_{8}-\mathrm{C}_{24}\right)$ as well as comparing their mass spectra and retention time with published data and Wiley Mass Spectral Data Base (Davies, 1990; Adams, 2007).

\subsection{Isolation of cuminic acid}

About $30 \mathrm{~g}$ of CVO were dissolved in the least amount of petroleum ether and adsorbed on $40 \mathrm{~g}$ silica gel to prepare initial zone and placed on the top of a silica column $(4 \times 60 \mathrm{~cm}, 300 \mathrm{~g})$ packed with petroleum ether. The column was eluted in a gradient elution technique using petroleum ether then methylene chloride and methanol, respectively. Fractions (200 $\mathrm{ml}$ each) were collected, concentrated, examined by silica gel TLC plates and similar fractions were combined. The first active fraction (VO-1) that eluted with $25 \%$ methylene chloride in petroleum ether was crystallized from petroleum ether afforded 1.2 gm cuminic acid as white needle crystals. It has m.p 115$118{ }^{\circ} \mathrm{C}$ and $\mathrm{R}_{\mathrm{f}}$ value 0.65 using silica gel TLC plates eluted with petroleum ether: ethyl acetate (6:4). It gives pink arch shaped 
spot upon visualization with anisaldehyde /sulphuric acid. O-cumenol, methyl palmiate , 3-(6-hydroxyhexyloxy)propyl cuminate and 3-(4-(4-(4-butoxybutoxy) butoxy) butoxy) propyl cuminate were detected by GC-MS as shown in table (3); Cuminaldehyde, myrtanol (cis), myrtenol (trans), cryptone (4-hydroxy), butylated hydroxytoluene, daucol, deca-2,4-dienyl cuminate, undeca-2,4-dienyl cuminate, 3-(6hydroxy hexyloxy) propyl cuminate and 3(4-(4-(4-butoxybutoxy) butoxy) butoxy)propyl cuminate were detected by GC-MS as shown in table (4).

\subsection{Biological Study}

Human hepatocellular carcinoma cell line Hep- $\mathrm{G}_{2}$ (ATCC, USA), were used to evaluate the cytotoxic effect of the tested oil fractions. Cytotoxicity was measured against Hep- $\mathrm{G}_{2}$ cells using the MTT Cell Viability Assay (Hansen et al., 1989).

\section{RESULTS}

GC-MS of the cumin oil showed 23 components constituting $99.28 \%$ of the oil content. Monoterpene hydrocarbons represented about $14.32 \%$ while oxygenated compounds represented about $84.96 \%$ of the oil content. Aldehyde percentage accounting for $39.34 \%$ of the oxygenated compounds. The major components was cuminaldehyde $(34.72 \%)$ as shown in Table (2). CVO exhibited potent cytotoxic activity against Hep-G2 cell line with IC $\mathrm{C}_{50} 2.4 \mu \mathrm{g} / \mathrm{ml}$.

GC-MS of the active fraction (VO-1) showed 5 components constituting 99.19 $\%$ of the volatile oil content which are only oxygenated compounds. The major component was cuminic acid (97.9\%) as shown in Table (3). VO-1 had cytotoxic activity against Hep- $\mathrm{G}_{2}$ cell line with $\mathrm{IC}_{50}=$ $0.6 \mu \mathrm{g} / \mathrm{ml}$.

GC-MS of the active fraction (VO-2) showed 10 components constituting $80.2 \%$ of the volatile oil content which are only oxygenated compounds. The major component was 3-(6-hydroxyhexyloxy) propyl cuminate (32.02 \%) as shown in
Table (4). VO-2 had cytotoxic activity against $\mathrm{Hep}-\mathrm{G}_{2}$ cell line with $\mathrm{IC}_{50}=0.9$ $\mu \mathrm{g} / \mathrm{ml}$.

Crystallization of active fraction VO1 lead to the isolation of pure compound with $\mathrm{IC}_{50}=6 \mu \mathrm{g} / \mathrm{ml}$ identified as cuminic acid. The structure of this compound was established using IR, mass, ${ }^{1} \mathrm{H}-\mathrm{NMR}$ and ${ }^{13} \mathrm{C}$-NMR.

\section{DISCUSSION}

CVO of the current study has qualitative and quantitative differences regarding chemical composition. This could be attributed to several factors among them is the geographical impact.

GC-MS analysis for CVO and both active fractions (VO-1 \& VO-2) were carried out to determine their chemical composition as shown in tables (1, 2 and 3). CVO, VO-1 \& VO-2 exhibited potent cytotoxic activity against Hep- $\mathrm{G}_{2}$ cell line with $\mathrm{IC}_{50}$ 2.4, 0.6 and $0.9 \mu \mathrm{g} / \mathrm{ml}$, respectively.

The structure of cuminic acid was established using IR, mass, ${ }^{1} \mathrm{H}-\mathrm{NMR}$ and ${ }^{13} \mathrm{C}-\mathrm{NMR}$ in comparison with published data (16) as follows:

IR spectrum indicates the presence of hydroxyl group at $3421 \mathrm{~cm}^{-1}$ in addition to carboxylic carbonyl group at $1685 \mathrm{~cm}^{-1}$. Other bands at $3063(\mathrm{C}=\mathrm{C}-\mathrm{H}), 2954(\mathrm{CH}-$ stretching) and $1608 \mathrm{~cm}^{-1}(\mathrm{C}=\mathrm{C})$ revealed the occurrence of an aromatic ring together with C-O stretching at $1423 \mathrm{~cm}^{-1}$ (15). MS spectrum showed molecular ion peak at $\mathrm{m} / \mathrm{z}$ 164 suggesting molecular formula $\mathrm{C}_{10} \mathrm{H}_{12} \mathrm{O}_{2}$ and base peak at $149\left(\mathrm{M}^{+}-\mathrm{CH}_{3}\right)$. Other fragmentation peaks at 131, 105, 91, 77 (16). ${ }^{1} \mathrm{H}$ NMR spectrum $\left(400 \mathrm{MHz}, \mathrm{CDCl}_{3}\right)$ showed signals characteristic for benzyl 
Table 2: Results of GC-MS analysis of the identified CVO components.

\begin{tabular}{|c|c|c|c|c|}
\hline No. & Compound & M.W & $\mathbf{R I}$ & Relative \% \\
\hline 1 & $\alpha$-Thujene & 136 & 924 & 0.31 \\
\hline 2 & $\alpha$-Pinene & 136 & 932 & 0.67 \\
\hline 3 & $\beta$-Pinene & 136 & 974 & 3.87 \\
\hline 4 & Myrecene & 136 & 988 & 0.63 \\
\hline 5 & $\delta$-3-Carene & 136 & 1008 & 0.05 \\
\hline 6 & $\alpha$-Terpinene & 136 & 1014 & 0.04 \\
\hline 7 & p-Cymene & 136 & 1020 & 2.04 \\
\hline 8 & $\gamma$-Terpinene & 136 & 1054 & 6.71 \\
\hline 9 & O-Cumenol & 136 & 1196 & 0.02 \\
\hline 10 & Cumin aldehyde & 148 & 1238 & 34.72 \\
\hline 11 & Car-3-en-2-one & 150 & 1244 & 4.48 \\
\hline 12 & Myrtanol (cis) & 154 & 1250 & 0.04 \\
\hline 13 & Myrtanol (trans) & 154 & 1258 & 0.1 \\
\hline 14 & $\gamma$-Terpinen-7-al & 150 & 1290 & 4.62 \\
\hline 15 & Cryptone(4-hydroxy) & 154 & 1314 & 1.36 \\
\hline 16 & Cuminic acid & 164 & 1417 & 16.72 \\
\hline 17 & Butylated hydroxytoluene & 220 & 1514 & 0.98 \\
\hline 18 & Daucol & 238 & 1641 & 6.33 \\
\hline 19 & Methyl palmiate & 270 & 1848 & 0.01 \\
\hline 20 & Deca-2,4-dienyl cuminate & 304 & 1891 & 1.48 \\
\hline 21 & Undeca-2,4-dienyl cuminate & 318 & 1930 & 3.92 \\
\hline 22 & 3-(6-hydroxyhexyloxy) Propyl cuminate & 324 & 1947 & 7.41 \\
\hline 23 & 3-(4-(4-(4-butoxybutoxy)butoxy)butoxy) Propylcuminate & \multirow[t]{2}{*}{502} & 2137 & 2.77 \\
\hline \multicolumn{2}{|r|}{ 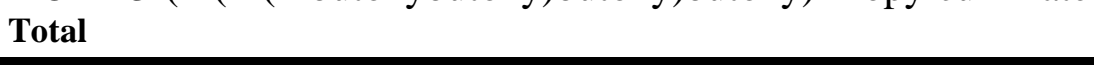 } & & & 99.28 \\
\hline No. & Compound & \multicolumn{2}{|l|}{ M.W } & Relative \% \\
\hline 1 & O-Cumenol & 136 & 1196 & 0.02 \\
\hline 2 & Cuminic acid & 164 & 1417 & 97.9 \\
\hline 3 & Methyl palmiate & 270 & 1848 & 0.11 \\
\hline 4 & 3-(6-hydroxyhexyloxy) Propyl cuminate & 324 & 1947 & 0.94 \\
\hline 5 & $\begin{array}{l}\text { 3-(4-(4-(4-butoxybutoxy) butoxy) butoxy) Propyl } \\
\text { cuminate }\end{array}$ & 502 & 2137 & 0.22 \\
\hline Tota & & & & 99.19 \\
\hline
\end{tabular}


Table 4: Results of GC-MS analysis for the identified components of active fraction (VO-2).

\begin{tabular}{clccc}
\hline No. & \multicolumn{1}{c}{ Compound } & M.W & RI & $\begin{array}{c}\text { Relative } \\
\text { \% }\end{array}$ \\
\hline 1 & Cuminaldehyde & 148 & 1238 & 6.98 \\
2 & Myrtanol (cis) & 152 & 1250 & 1.24 \\
3 & Myrtenol (trans) & 152 & 1258 & 1.64 \\
4 & Cryptone(4-hydroxy) & 154 & 1314 & 5.54 \\
5 & Butylated hydroxytoluene & 220 & 1514 & 3.87 \\
6 & Daucol & 238 & 1641 & 10.02 \\
7 & Deca-2,4-dienyl cuminate & 304 & 1891 & 2.16 \\
8 & Undeca-2,4-dienyl cuminate & 318 & 1930 & 7.36 \\
9 & 3-(6-hydroxyhexyloxy) Propyl cuminate & 324 & 1947 & 32.02 \\
10 & 3-(4-(4-(4-butoxybutoxy) butoxy) & 502 & 2137 & 9.37 \\
& butoxy) Propyl cuminate & & & \\
Total & & & & 80.2 \\
\hline
\end{tabular}

\section{Conclusion}

It is noteworthy that, bioguided fractionation of potent CVO ( $\mathrm{IC}_{50} 2.4 \mu \mathrm{g} / \mathrm{ml}$ ) using silica gel column chromatography afforded extremely potent two active fractions (VO-1and VO-2) with $\mathrm{IC}_{50}=0.6$ and $0.9 \mu \mathrm{g} / \mathrm{ml}$, respectively. Crystallization of active fraction VO-1 lead to the isolation of cuminic acid which had moderate cytotoxic activity against $\mathrm{Hep}-\mathrm{G}_{2}$ cell line with $\mathrm{IC}_{50}=6 \mu \mathrm{g} / \mathrm{ml}$. This indicates the synergistic effect between the volatile oil components in CVO, VO-1and VO-2, respectively. moiety by appearance of two broad doublet signals at $\delta 8.02(\mathrm{~J}=8 \mathrm{~Hz} ; \mathrm{H}$ 3, H-5), 7.31(J= $8 \mathrm{~Hz}$; H-2, H-6). The multiplet signal at $\delta 2.98(\mathrm{H}-7)$ in addition to doublet signal at $\delta 1.27(\mathrm{~J}=8 \mathrm{~Hz} ; 6 \mathrm{H})$ indicating the presence of isopropyl group (16). ${ }^{13} \mathrm{C}$ NMR spectrum (100 $\left.\mathrm{MHz}, \mathrm{CDCl}_{3}\right)$ revealed the presence of carbonyl carbon at $\delta$ 171.41, in addition to six carbons corresponding to the carbons of benzyl moiety: C-2 and C-6 at $\delta 127.07$; C-3 and C5 at $\delta 126.76 ; \mathrm{C}-1$ at $\delta 155.4$ and $\mathrm{C}-4$ at $\delta$ 130.53. Also, the signal at $\delta 23.83\left(\mathrm{CH}_{3}\right)$ in addition to a signal at $\delta 34.49$, for $3^{\text {ry }}$ carbon, characteristic for isopropyl group ${ }^{(16)}$.

Cuminic acid which was previously isolated from the petroleum ether extract of cumin in China.

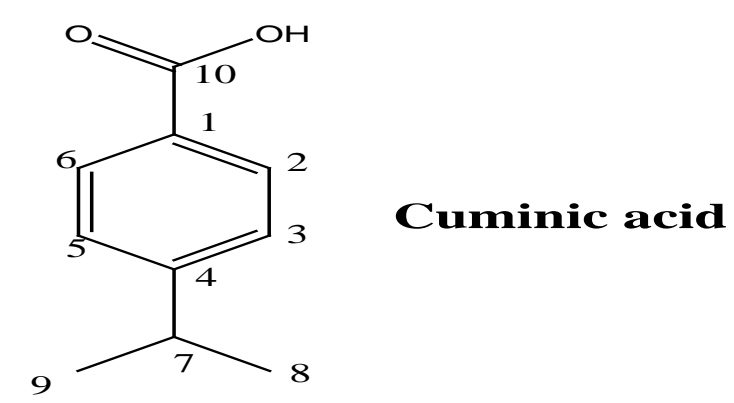

\section{REFERENCES}

Adams, R. P. (2007) Identification of essential oils components By gas chromatography and mass spectroscopy, $4^{\text {th }}$ ed. Baylor University, Waco, Texas.

Allahghadri T., Rasooli I., Owlia P., Nadooshan M.J., Ghazanfari T., Taghizadeh $M$. andAstaneh S.D. (2010) Antimicrobial property, antioxidant capacity and cytotoxicity of essential oil from cumin produced in Iran, J Food Sci., 75(2):54-61.

Daljeet K. and Ramica S. (2012) An Update on Pharmacological Properties of Cumin, IJRPS, 2(4): 14-27.

Davies N. W. (1990) Gas chromatographic retention indices of monoterpenes and sesquiterpenes on methyl silicon and 
carbowax $20 \mathrm{M}$ phases, J chromatogr A, 503: 1-24.

El-Ghorab A. H., Nauman M., Anjum F. M., Hussain S. and Nadeem M. A. (2010) Comparative study on chemical composition and antioxidant activity of ginger (Zingiber officinale) and cumin (Cuminum cyminum), J Agric Food Chem. , 58(14): 8231-7.

EL-Kamali H. H., Adam S.I.Y, Adam A.S, Abbakar F.M. and Babikir I.A. (2009) Aromatic Plants from the Sudan: Part I. Chemical Composition and Antibacterial Activity of Cuminum cyminum $L$. Essential Oil, Advances in Natural and Applied Sciences, 3(1): 1-4.

Hansen M. B., Nielsen S. E. and Berg K. (1989) Reexamination and further development of a precise and rapid dye method for measuring cell growth/cell kill, J. Immunol. Methods, 119: 203-210.

Hu L.F., FengJ.T, Zhang X., ZhangY.I. (2007) Isolation and Structure Detection of Fungicidal Components from Cuminum cyminum Seed, Chinese Journal of Pesticide Science, 9(4): 330-334.

Kuen-daw T., Yi-Heng L., Ta-Wei C., Shu-Mei Y., Ho-Yiu W. , Jonathan C., Kuo-Shen C. and Jaw-Ming C. (2016) Cuminaldehyde from Cinnamomum verum Induces Cell Death through Targeting Topoisomerase 1 and 2 in Human Colorectal Adenocarcinoma COLO 205 Cells, Nutrients , 8: 318.

Latif G., Davood Y., Mohammad B. R., Masood A, Shakiba A. and Iraj R. (2007) Chemical and biological characteristics of Cuminum cyminum and Rosmarinus officinalis essential oils, Food Chemistry, 102(3): 898-904.

Marianna V.S., Aline L.X., Tamires C. L. and Damião P. S. (2014) Review Article: Antitumor Activity of Monoterpenes Found in Essential Oils, The Scientific World Journal: 1-35.

Nicola S. I., Pietro Lo C., Francesco C. and Felice S. (2005) Antibacterial Activity of Cuminum cyminum L. and Carum carvi L. Essential Oils, J. Agric. Food Chem., 53: 57-61.

Nisha C., Shahnaz S. H. and Mohammed A. (2014) Chemical Composition and Antimicrobial Activity of Volatile Oil of The Seeds of Cuminum cyminum L, World Journal of Pharmacy and Pharmaceutical Sciences, 3(7): 1428-1441.

Rasha S., Mansour S., Mohamed L., Mahmoud Z. E. R. , Samar Y. D., Raimund N., Ashraf H. A. and Michael W. (2014) Chemical composition and biological activity of the essential oils of cumin and coriander fruits from Egypt, The Natural Products Journal, 4: 63-69.

Uma A., Dharam P. P., Garima K., Rubina B., Ruchi R., Vikas G. and Ravi K. (2017) Review on Cuminum cyminum -Nature's Magical Seeds, Journal of Chemical and Pharmaceutical Research, 9(9): 180-187.

Yamaguchi K. (1970) Spectral Data of Natural Products, $1^{\text {st }}$ Elservier Publishing Company, Amesterdam, London, New York. 


\section{استجلاء الأثر المضاد للتسرطن واستخلاص المكونات ذات الأثز السام لسرطان الكبا لخلاصة الزيت} الطيار للكمون

محمود محمد عبدالعال, عزة محمد الثافعي, ماجد محمد ماهر ابو هاثم, عبدالمنعم محمد عطيه,

$$
\text { مني فكري }
$$

قسم العقاقير، كلية الصيدلة ، جامعة الزقازيق ، 44519 الزقازيق ، مصر

يمكن استخدام الزيوت الطيارة للكثير من النباتات للحصول علي أدوية ذات قيمة عالية. و قد كان الهدف مـن هذه الدر اسة هو استجلاء الأثر المضاد لتسـرطن الكبـد الخلاصــة الزيـت الطبـار للكمـون باسـتخدام الخلايـا الكبدية (Hep-G2). أظهرت هذة الخلاصة فعالية قوية ضد تسرطن الكبد (2.4 مكجم /مـل). فعن طريق

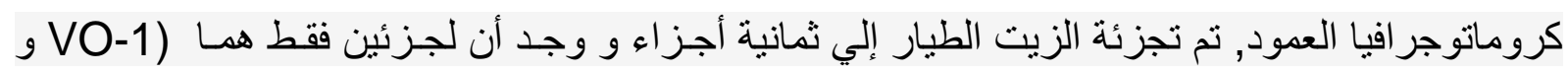
فعالية قوية ضـد تسـرطن الكبد (نصف التأثير المثبط الأقصسي 0.6 و 0.9 مكجم /مـل) على ولى التو الي و باستخدام كروماتوجر افيا الغاز للزيت الطيار والجزئين النشطين نم التعرف علي التركيب الكيميائي

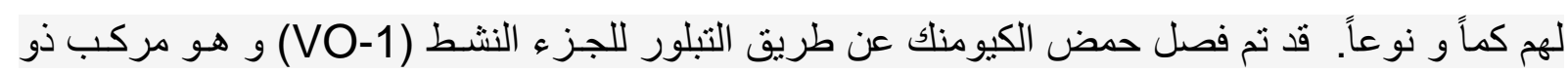

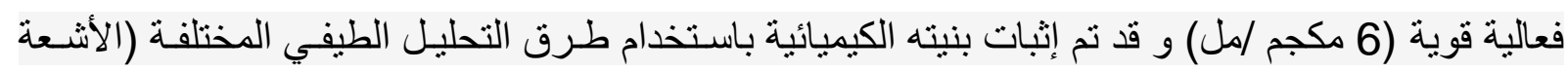
تحت الحمر اء, مطياف الكتلة و الرنين المغناطيسي للبروتون و الكربون) . 